\title{
Melatonin inhibits RANKL-induced osteoclastogenesis through the miR-882/Rev-erbo axis in Raw264.7 cells
}

\author{
YIHAO TIAN, ZUNLEI GONG, RUI ZHAO and YUE ZHU
}

Department of Orthopaedics, The First Affiliated Hospital of China Medical University, Shenyang, Liaoning 110001, P.R. China

Received June 9, 2020; Accepted November 24, 2020

DOI: $10.3892 / \mathrm{ijmm} .2020 .4820$

\begin{abstract}
Melatonin, secreted in a typical diurnal rhythm pattern, has been reported to prevent osteoporosis; however, its role in osteoclastogenesis remains unclear. In the present study, the ability of melatonin to inhibit receptor activator of nuclear factor- $\kappa \mathrm{B}$ ligand (RANKL)-induced osteoclastogenesis and the associated mechanism were investigated. Raw264.7 cells were cultured with RANKL (100 $\mathrm{ng} / \mathrm{ml})$ and macrophage colony-stimulating factor (M-CSF; $30 \mathrm{ng} / \mathrm{ml}$ ) for 7 days, and tartrate-resistant acid phosphatase (TRAP) staining was used to detect osteoclastogenesis following treatment with melatonin. In addition, the effect of melatonin on cathepsin $\mathrm{K}$ and microRNA (miR)-882 expression was investigated via western blotting and reverse transcription-quantitative PCR. Melatonin significantly inhibited RANKL-induced osteoclastogenesis in Raw264.7 cells. From bioinformatics analysis, it was inferred that nuclear receptor subfamily 1 group D member 1 (NR1D1/Rev-erb $\alpha$ ) may be a target of miR-882. In vitro, melatonin upregulated Rev-erb $\alpha$ expression and downregulated miR-882 expression in the osteoclastogenesis model. Rev-erb $\alpha$ overexpression boosted the anti-osteoclastogenesis effects of melatonin, whereas miR-882 partially diminished these effects. The present results indicated that the miR-882/Rev-erb $\alpha$ axis may serve a vital role in inhibiting osteoclastogenesis following RANKL and M-CSF treatment, indicating that Rev-erb $\alpha$ agonism or miR-882 inhibition may represent mechanisms through which melatonin prevents osteoporosis.
\end{abstract}

Correspondence to: Professor Yue Zhu, Department of Orthopaedics, The First Affiliated Hospital of China Medical University, 155 Nanjing North Street, Heping, Shenyang, Liaoning 110001, P.R. China

E-mail: zhuyuedr@163.com

Abbreviations: AMPK, AMP-activated protein kinase; RANKL, receptor activator of nuclear factor- $\mathrm{KB}$ ligand; OPG, osteoprotegerin; TRAP, tartrate-resistant acid phosphatase; M-CSF, macrophage colony-stimulating factor; UTR, untranslated region; Rev-erb $\alpha /$ NR1D1, nuclear receptor subfamily 1 group D member 1

Key words: melatonin, osteoclasts, microRNA-882, Rev-erb $\alpha$, osteoclastogenesis

\section{Introduction}

Osteoporosis is an increasingly serious life-threatening medical issue (1-4). It often results in fractures, with associated complications such as hypostatic pneumonia, deep-vein thrombosis and bedsores, which can be fatal (5). Osteoporosis occurs due to a decrease in the number/activity of osteoblasts and/or increase in the number/activity of osteoclasts (6). The pathogenesis of osteoporosis involves complex signaling pathway regulation and protein modification, and a lot about this process remains unknown (7-9). In the past years, research has identified key signalling molecules that modulate bone formation and/or bone resorption, including Wnt $(10,11)$, Akt $(12,13)$, MAPK $(14,15)$, AMP-activated protein kinase (AMPK) $(16,17)$, receptor activator of nuclear factor- $\kappa \mathrm{B}$ ligand (RANKL) $(18,19)$, osteoprotegerin (OPG) $(20,21)$ and tumor necrosis factor superfamily member 14 (22). Currently, there is no efficacious anti-osteoporosis treatment with minimal side effects; thus, there is an urgent unmet medical need for novel treatment strategies.

Bone homeostasis is maintained through osteogenesis and osteoclastogenesis (23). Osteoclasts originate via a process of differentiation from hematopoietic stem cells or monocytes (24). Osteoclast differentiation (or osteoclastogenesis) involves multiple steps, which include transformation into tartrate-resistant acid phosphatase (TRAP)-positive cells, merging into multinucleated cells, activating bone resorption and finally undergoing spontaneous apoptosis (25). RANK, its cellular ligand RANKL, macrophage colony-stimulating factor (M-CSF) and OPG (a decoy soluble receptor for RANKL) are four critical factors for osteoclastogenesis $(26,27)$. RANKL is highly conserved and is a member of the TNF family (28). RANK (encoded by Tnfrsfl1a) is a receptor activator of nuclear factor- $\kappa \mathrm{B}$, which is expressed via M-CSF stimulation on the surface of Raw264.7 cells (29). OPG competitively inhibits the binding of RANKL to RANK, and polymorphisms in the $O P G$ gene are associated with osteoporosis $(30,31)$. Furthermore, the interaction between M-CSF and CSF1 receptor is crucial for proliferation and differentiation in osteoporosis (32).

The existing drugs for osteoporosis are inefficient and produce unsatisfactory results (33); therefore, it is critical to develop safe and effective treatment options. Natural substances provide a new avenue for the treatment of osteoporosis. Melatonin is a methoxyindole that is synthesized in, and secreted predominantly from, the pineal gland (34). Although 
it is also synthesized in mitochondria, virtually every cell can produce melatonin, including cells of the bone marrow (35). This secretion is performed at night as part of the circadian rhythm; the schedule of the circadian rhythm is orchestrated by the suprachiasmatic nuclei and synchronized with the light/dark cycle (34). Furthermore, light can inhibit melatonin production (36). The biological rhythm of melatonin can be estimated by the melatonin content in the plasma/saliva or by measuring urinary 6-sulfatoxymelatonin, the primary hepatic metabolite $(34,37,38)$. Some studies have determined that melatonin may reinforce the coupling of rhythms, such as the sleep/wake cycle and core temperature, although these findings are based on clinical trial information $(34,39,40)$. Sánchez-Barceló et al (41) summarized the physiological effect of melatonin on the bone. Specifically, low concentrations (in the $\mu \mathrm{M}$ range) of melatonin were found to promote the proliferation and differentiation of osteoblasts and the expression levels of bone differentiation markers (such as type I collagen, osteopontin, bone sialoprotein and osteocalcin) (41). Additionally, melatonin can simultaneously inhibit osteoclast differentiation by promoting OPG secretion and eliminating the free radicals produced by osteoclasts (41). However, the underlying mechanism by which melatonin exerts its effects on individuals afflicted by osteoporosis remains to be identified. Thus, the current study aimed to investigate the effects of melatonin on RANKL-induced osteoclastogenesis in Raw264.7 cells.

\section{Materials and methods}

Cell culture. Raw264.7 cells (The Cell Bank of Type Culture Collection of the Chinese Academy of Sciences) were cultured in DMEM containing $10 \%$ FBS and $1 \%$ streptomycin and penicillin (all HyClone; Cytiva) in a $37^{\circ} \mathrm{C}$ incubator with $5 \% \mathrm{CO}_{2}$ and maximum humidity. The culture medium was replenished daily. Cells were incubated in serum-free medium $24 \mathrm{~h}$ before treatment. Raw264.7 cells were cultured for 7 days with $100 \mathrm{ng} / \mathrm{ml}$ RANKL (R\&D Systems, Inc.) and $30 \mathrm{ng} / \mathrm{ml} \mathrm{M-CSF}$ (R\&D Systems, Inc.) in the presence of varying concentrations $(0.1$ or $1 \mu \mathrm{mol})$ of melatonin (Sigma-Aldrich; Merck KGaA; Fig. 1A) for $48 \mathrm{~h}$ at $37^{\circ} \mathrm{C}$. Raw264.7 cells were cultured in the presence of varying concentrations of SR9009 $(5,10$ and $15 \mu \mathrm{mol}$; MedChemExpress; Fig. 1B) or SR8278 (5, 10 and $15 \mu \mathrm{mol}$; MedChemExpress; Fig. 1C) for $48 \mathrm{~h}$ at $37^{\circ} \mathrm{C}$.

Synthetic RNA oligonucleotides and transfection. MicroRNA (miR)-882 mimics, miR-882 mimic negative control (NC), miR-882 inhibitors and miR-882 inhibitor NC were obtained from Shanghai GenePharma Co., Ltd. Raw264.7 cells were transfected with Lipofectamine ${ }^{\circledR} 2000$ (Invitrogen; Thermo Fisher Scientific, Inc.) for $6-8 \mathrm{~h}$ at $37^{\circ} \mathrm{C}$, according to the manufacturer's instructions. The type of NCs used was a non-sense sequence. The concentration of miR-882 mimics/inhibitors used for transfection was $20 \mu \mathrm{M}$. RNA was extracted $24 \mathrm{~h}$ after transfection, and protein was extracted $48 \mathrm{~h}$ after transfection. The sequences of all miR-882 mimics and inhibitors were as follows: miR-882 mimics sense, 5'-AGGAGAGAGUUAGCG CAUUAGU-3' and antisense, 5'-UAAUGCGCUAACUCU CUCCUUU-3'; miR-882 mimics NC sense, 5'-UUCUCCGAA CGUGUCACGUTT-3' and antisense, 5'-ACGUGACACGUU
CGGAGAATT-3'; miR-882 inhibitors, 5'-ACUAAUGCGCUA ACUCUCUCCU-3'; miR-882 inhibitors NC, 5'-CAGUAC UUUUGUGUAGUACAA-3.

$R N A$ extraction and reverse transcription-quantitative PCR. The TRIzol ${ }^{\circledR}$ Reagent kit (Qiagen Sciences, Inc.) was used to extract total RNA from cells according to the manufacturer's protocol. miRNA and mRNA reverse-transcription PCR was performed using the Mir-X miRNA qRT-PCR TB Green ${ }^{\circledR}$ kit (cat. no. 638314; Clontech Laboratories, Inc.) for miRNA and the PrimeScript ${ }^{\mathrm{TM}}$ RT reagent kit with gDNA Eraser (cat. no. RR047A; Takara Biotechnology Co., Ltd.) for mRNA according to the manufacturer's protocol. The QuantiTect SYBR-Green PCR kit (cat. no. RR820A; Takara Biotechnology Co., Ltd.) was used to perform real-time quantitative PCR. The thermocycling conditions are as follows: Initial denaturation at $95^{\circ} \mathrm{C}$ for $30 \mathrm{sec}$, followed by 40 cycles at $95^{\circ} \mathrm{C}$ for $5 \mathrm{sec}$ and $60^{\circ} \mathrm{C}$ for $30 \mathrm{sec}$, one cycle at $95^{\circ} \mathrm{C}$ for $5 \mathrm{sec}, 60^{\circ} \mathrm{C}$ for $1 \mathrm{~min}$ and $95^{\circ} \mathrm{C}$, and finally annealing at $50^{\circ} \mathrm{C}$ for $30 \mathrm{sec}$. The results were analyzed using a Roche Light Cycler $^{\circledR} 480$ II system (Roche Diagnostics). The relative expression of miR-882 was standardized to U6 RNA expression, while mRNA relative expression was standardized to GAPDH mRNA expression using the well-accepted $2^{-\Delta \Delta \mathrm{Cq}}$ method (42). For detailed information see section Performing a Basic Relative Quantification Experiment. The following primer sequences were used: miR-882 forward, 5'-CGCAGGAGAGAGTTAGCGCATTAGT-3' and reverse primer was taken by Universal sequence; U6 forward, 5'-CGC TTCGGCAGCACATATAC-3' and reverse, 5'-TTCACGAAT TTGCGTGTCAT-3'; cathepsin K forward, 5'-GAAGAAGAC TCACCAGAAGCAG-3' and reverse, 5'-TCCAGGTTATGG GCAGAGATT-3'; NR1D1 forward, 5'-TACATTGGCTCTAGT GGCTCC-3' and reverse, 5'-CAGTAGGTGATGGTGGGA AGTA-3'; and GAPDH forward, 5'-AGGTCGGTGTGAACG GATTTG-3' and reverse, 5'-TGTAGACCATGTAGTTGAGGT CA-3'.

Western blot analysis. Raw264.7 cells were lysed in RIPA buffer containing phenylmethanesulfonyl fluoride (both Beyotime Institute of Biotechnology), followed by centrifugation at $4^{\circ} \mathrm{C}$ at $12,000 \times \mathrm{g}$ for $30 \mathrm{~min}$. Quantitative analysis of protein concentration was performed using a BCA assay kit (Beyotime Institute of Biotechnology), and each sample was loaded at a concentration of $3 \mu \mathrm{g} / \mu \mathrm{l}$ in RIPA and loading buffer. Samples were separated via $10 \%$ SDS-PAGE at $80 \mathrm{~V}$ and the proteins were transferred to polyvinylidene difluoride membranes at $200 \mathrm{~mA}$ for $60 \mathrm{~min}$. The membranes were blocked with 5\% BSA (Beijing Solarbio Science \& Technology Co., Ltd.) for $2 \mathrm{~h}$ at room temperature and incubated with primary antibodies diluted in TBS-Tween (TBST; Beijing Solarbio Science \& Technology Co., Ltd.; cat. no. T1081) at concentrations according to the manufacturer's instructions overnight at $4^{\circ} \mathrm{C}$. The following primary antibodies were used: Anti-cathepsin K (Abcam; cat. no. ab19027; 1:1,000), anti-nuclear receptor subfamily 1 group D member 1 (NR1D1/Rev-erba; Abcam; cat. no. ab174309; 1:5,000) and anti-GAPDH (ProteinTech Group, Inc.; cat. no. 10494-1-AP; 1:10,000). After primary antibody incubation, the membranes were washed thrice and incubated with an HRP-conjugated goat anti-rabbit IgG secondary antibody (ProteinTech Group, Inc.; 


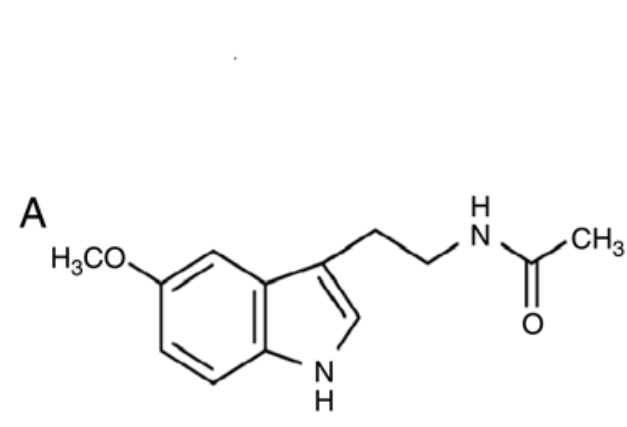

Melatonin chemical structure

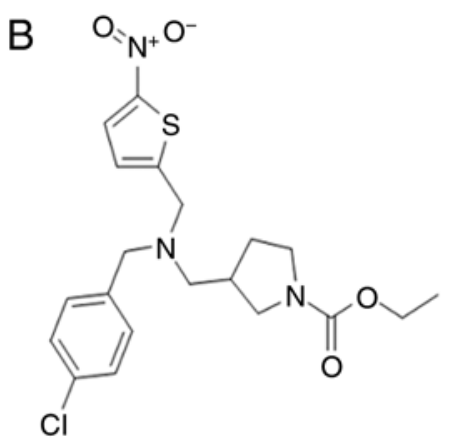

SR9009 chemical structure

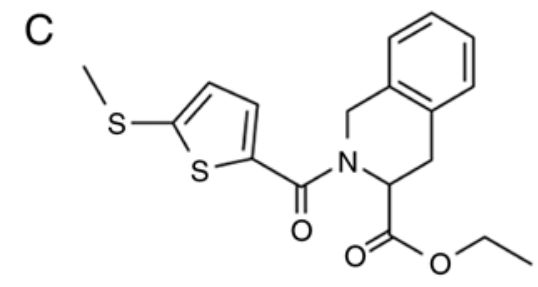

SR8278 chemical structure

Figure 1. Chemical structures of melatonin, SR9009, and SR8278. (A) Chemical structure of melatonin. (B) Chemical structure of SR9009. (C) Chemical structure of SR8278.

cat. no. SA00001-2; 1:10,000) diluted in TBST for $2 \mathrm{~h}$ at room temperature. An Ultrasensitive Enhanced Chemiluminescence Detection kit (ProteinTech Group, Inc.; cat. no. PK10002) was used as the visualization reagent. ImageJ software (v1.52; National Institutes of Health) was used for densitometry.

TRAP staining. Raw264.7 cells were plated in 6-well plates $\left(3,000\right.$ cells $\left./ \mathrm{cm}^{2}\right)$ and cultured in medium containing $100 \mathrm{ng} / \mathrm{ml}$ RANKL and $30 \mathrm{ng} / \mathrm{ml} \mathrm{M-CSF}$ for 7 days at $37^{\circ} \mathrm{C}$ prior to TRAP staining, with or without 0.1 or $1 \mu \mathrm{M}$ melatonin. Plates were washed with PBS and fixed with $4 \%$ paraformaldehyde for $15 \mathrm{~min}$ at $37^{\circ} \mathrm{C}$. TRAP staining working solution was added to the plates and incubated for $60 \mathrm{~min}$ at $37^{\circ} \mathrm{C}$ in the dark. TRAP staining was performed using an acid phosphatase leukocyte kit (Sigma-Aldrich; Merck KGaA; cat. no. 387) in accordance with the manufacturer's protocol. Representative images were acquired using an Eclipse Ti fluorescence microscope (Nikon Corporation; magnification, x200 and 400). TRAP-positive cells containing $>3$ nuclei were recorded as osteoclasts.

Cell Counting Kit-8 (CCK-8) assay for cell viability. Raw264.7 cells were plated in 96-well plates at a concentration of $5 \times 10^{3}$ cells/well. After $24 \mathrm{~h}$, melatonin $(0.1,1$ or $10 \mu \mathrm{mol}$ ), the Rev-erb $\alpha$ agonist SR9009 (Fig. 1B) or antagonist SR8278 (Fig. 1C) was added. After $48 \mathrm{~h}$ at $37^{\circ} \mathrm{C}$, CCK-8 reagent (Dojindo Molecular Technologies, Inc.) was added for 30-60 min to detect cell activity according to the manufacturer's instructions. The results were analyzed with an automated enzyme-linked immunosorbent assay reader ELx808 (BioTek Instruments, Inc.; Agilent Technologies, Inc.) at $450 \mathrm{~nm}$. Cell activity was expressed as OD value.

Target gene prediction. Potential miRNAs that could target Rev-erb $\alpha$ were first predicted by collecting information from databases including TargetScan (http://www.targetscan.org/), miRDB (http://mirdb.org/) and DIANA (http://diana.imis. athena-innovation.gr/), followed by organizing and consolidating these data.

Dual-luciferase reporter assay. Plasmid transfections for luciferase assays in 293T cells (purchased from The Cell Bank of Type Culture Collection of the Chinese Academy of Sciences, cultured with DMEM with $10 \%$ FBS in a $37^{\circ} \mathrm{C}$ incubator with $5 \% \mathrm{CO}_{2}$ ) were performed with $0.1 \mu \mathrm{g}$ reporter constructs (pMIR-REPORT-wild-type-Rev-erb $\alpha$ or pMIR-REPORT-mutant-Rev-erb $\alpha$ plasmids; Shanghai GeneChem Co., Ltd.) and $0.4 \mu \mathrm{g}$ miR-882 expression plasmid (Shanghai GeneChem Co., Ltd.), in a 24-well plate using Roche X-tremeGENE HP (Roche Diagnostics; cat. no. 06366236001) according to the manufacturer's instructions. Luciferase activity was measured $48 \mathrm{~h}$ post-transfection using the Dual Luciferase Reporter Assay System according to the manufacturer's instructions (Promega Corporation). Firefly luciferase activity was normalized to Renilla luciferase activity.

Statistical analysis. All data were analyzed using SPSS 22.0 software (IBM Corp.) and GraphPad Prism 6.0 (GraphPad Software, Inc.). Each group of experiments was repeated thrice independently, and the values are expressed as the mean \pm SD. In the present study, one-way ANOVA followed by Dunnett's post-hoc test was used for determining whether $\geq 3$ groups were statistically different from each other, while an unpaired t-test was used to determine whether 2 groups were statistically different from each other. $\mathrm{P}<0.05$ was used to indicate a statistically significant difference.

\section{Results}

Melatonin inhibits RANKL-induced osteoclastogenesis in Raw264.7 cells. To study the effect of melatonin on osteoclastogenesis, the mRNA and protein expression levels of cathepsin K were examined in Raw264.7 cells cultured for 7 days with RANKL (100 $\mathrm{ng} / \mathrm{ml})$ and M-CSF (30 ng/ml) in the presence of varying concentrations $(0.1$ or $1 \mu \mathrm{mol})$ of melatonin for $48 \mathrm{~h}$. Cathepsin $\mathrm{K}$ was analyzed since its expression represents the level of osteoclastogenesis (43). Melatonin decreased both the mRNA and protein expression levels of cathepsin $\mathrm{K}$ following RANKL and M-CSF treatment (Fig. 2A and B). Cell differentiation was further studied using TRAP staining in Raw264.7 cells cultured for 7 days with RANKL and M-CSF in the presence of melatonin for $48 \mathrm{~h}$. Melatonin treatment decreased the number of TRAP-positive cells following RANKL treatment (Fig. 2C). Subsequently, the viability of Raw264.7 cells was analyzed in the presence of varying concentrations $(0.1,1$ or $10 \mu \mathrm{mol})$ of melatonin for $48 \mathrm{~h}$ using the CCK-8 assay. Cell viability was expressed as OD value. The results revealed that melatonin was not cytotoxic to Raw264.7 cells (Fig. 2D). The present findings indicated that 
A
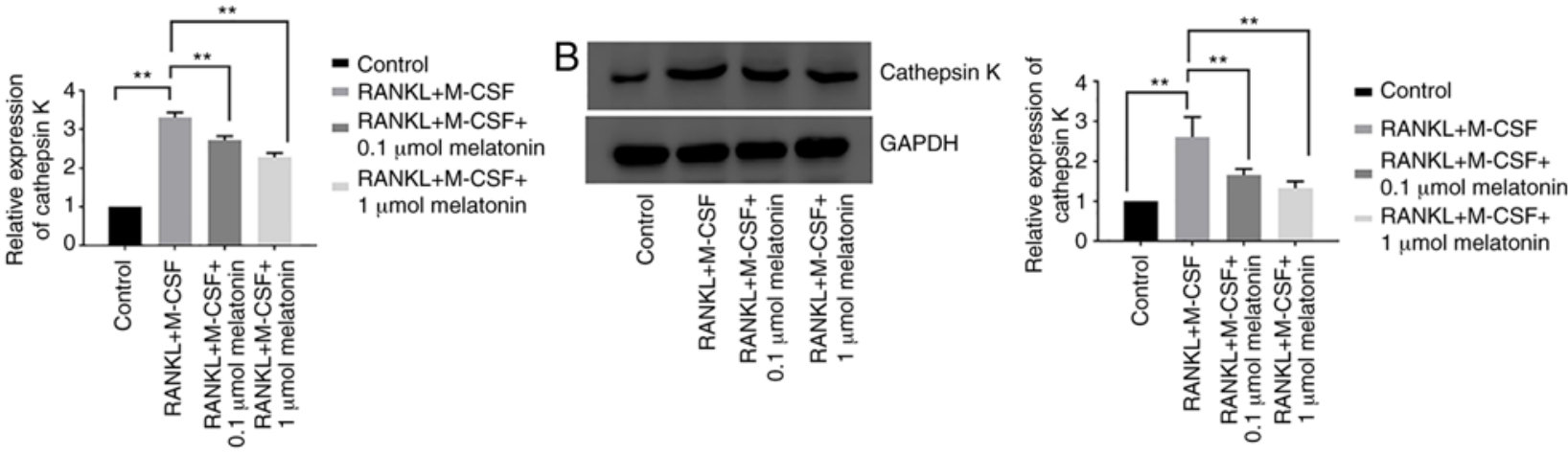

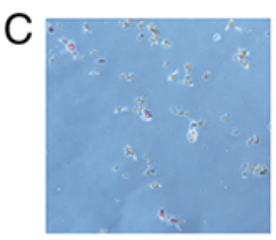

Control

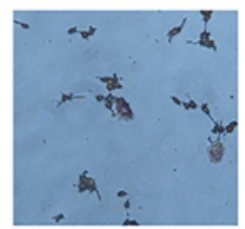

Control

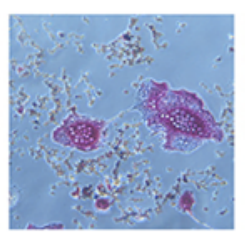

RANKL+M-CSF

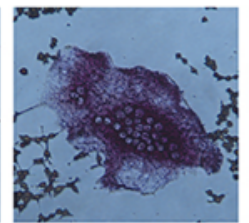

RANKL+M-CSF

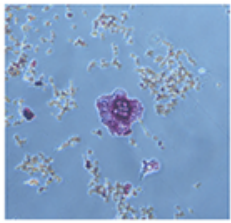

RANKL+M-CSF+ $0.1 \mu \mathrm{mol}$ melatonin

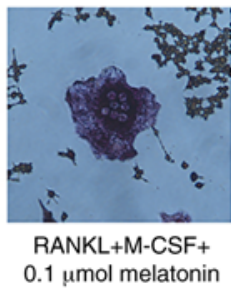

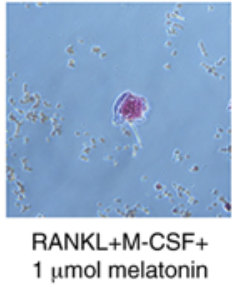

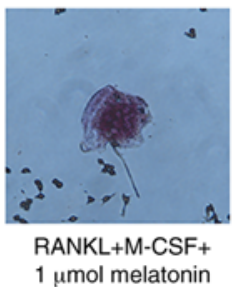

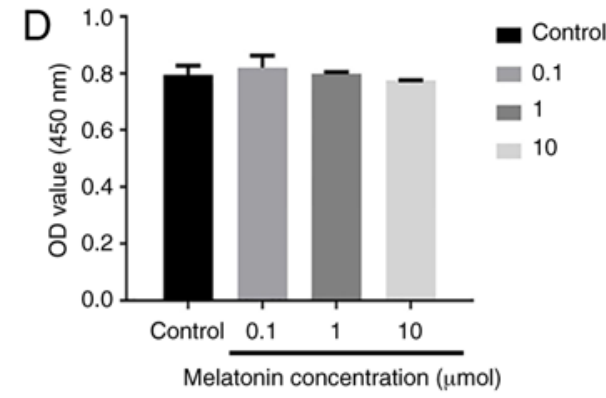

Figure 2. Melatonin inhibits RANKL-induced osteoclastogenesis in Raw264.7 cells. Cathepsin K (A) mRNA and (B) protein expression in Raw264.7 cells cultured for 7 days with RANKL (100 ng/ml) and M-CSF (30 ng/ml) in the presence of varying concentrations (0.1 or $1 \mu \mathrm{mol})$ of melatonin. (C) Tartrate-resistant acid phosphatase activity in Raw264.7 cells cultured for 7 days with RANKL (100 ng/ml) and M-CSF (30 ng/ml) in the presence of varying concentrations $(0.1$ or $1 \mu \mathrm{mol}$ ) of melatonin. Magnification, $\mathrm{x} 200$ (upper panels) and x400 (bottom panels). (D) Viability of Raw264.7 cells in the presence of varying concentrations $(0.1,1$ or $10 \mu \mathrm{mol})$ of melatonin. Cell viability was expressed as OD value. Data are represented as the mean $\pm \mathrm{SD}(\mathrm{n}=3)$. ${ }^{* *} \mathrm{P}<0.01 . \mathrm{OD}, \mathrm{optical}$ density; RANKL, receptor activator of nuclear factor- $\kappa \mathrm{B}$ ligand; M-CSF, macrophage colony-stimulating factor.

melatonin significantly inhibited RANKL-induced osteoclastogenesis in Raw264.7 cells without any observed cytotoxicity.

Melatonin enhances Rev-erba expression in Raw264.7 cells. During RANKL-induced osteoclast differentiation, both mRNA and protein expression levels of Rev-erb $\alpha$ were suppressed compared with the control group, which indicated that the inhibitory effect of melatonin on osteoclastogenesis may be associated with Rev-erb $\alpha$ (Fig. 3A and B). By contrast, the addition of melatonin ( 0.1 or $1 \mu \mathrm{mol})$ significantly upregulated Rev-erb $\alpha$ mRNA and protein expression in Raw264.7 cells cultured with RANKL and M-CSF (Fig. 3A and B).

Rev-erba activation boosts the effect of melatonin on the inhibition of osteoclastogenesis, whereas Rev-Erba inhibition promotes osteoclastogenesis. Raw 264.7 cells were treated with the Rev-erba agonist SR9009 or antagonist SR8278 to assess the function of Rev-erb $\alpha$ in osteoclastogenesis. The viability of Raw264.7 cells was analyzed in the presence of varying concentrations of SR9009 $(5,10$ and $15 \mu \mathrm{mol})$ or SR8278 $(5,10$ and $15 \mu \mathrm{mol})$ for $48 \mathrm{~h}$ via CCK-8 assay. SR9009 and SR8278 were not toxic to Raw264.7 cells at the concentrations tested (Fig. 4A and B). Western blotting revealed that in Raw264.7 cells cultured with RANKL, M-CSF and melatonin (1 $\mu \mathrm{mol})$, osteoclastogenesis was inhibited by melatonin more significantly in cells treated with the Rev-erb $\alpha$ agonist SR9009 compared with the osteoclastogenesis process in cells cultured without SR9009 (Fig. 4C). The Rev-erb $\alpha$ antagonist SR8278 hampered the ability of melatonin to influence osteoclastogenesis in Raw264.7 cells cultured with RANKL, M-CSF and $1 \mu \mathrm{mol}$ melatonin (Fig. 4D). Overall, these results indicated that the inhibitory effect of melatonin on osteoclastogenesis may be mediated by Rev-erba.

miR-882 regulates Rev-erb a protein expression. Subsequently, whether Rev-erb $\alpha$ expression was regulated by miRNAs was investigated. Potential miRNAs that could target Rev-erb $\alpha$ were first predicted by collecting information from databases including TargetScan, miRDB and DIANA, followed by organizing and consolidating these data. The overlapping miRNAs across different databases are shown in the Venn diagram in Fig. 5A. Since miR-882 was identified by the intersection of the three databases, it was hypothesized that miR-882 may regulate Rev-erb $\alpha$ mRNA expression. Raw264.7 cells were transfected with miR-882 mimics, inhibitors or corresponding NCs. miR-882 expression in Raw264.7 cells transfected with miR-882 mimics was significantly higher than that with the mimic-NC; additionally, Raw264.7 cells transfected with miR-882 inhibitors exhibited the opposite effect (Fig. 5B). Subsequently, whether Rev-erb $\alpha$ expression may be modulated 


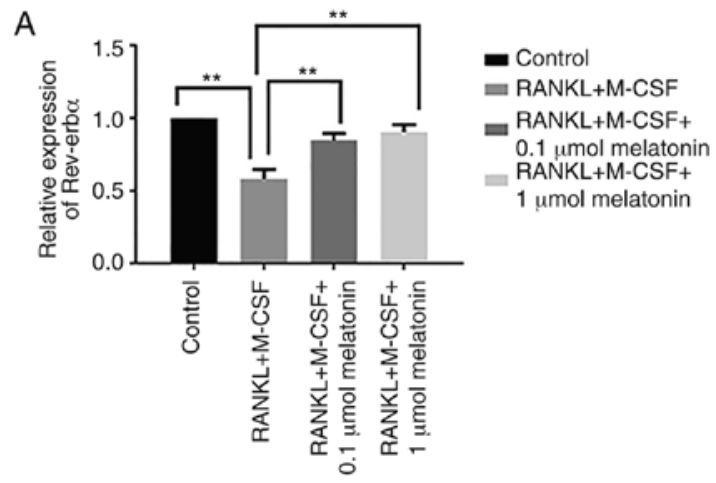

B
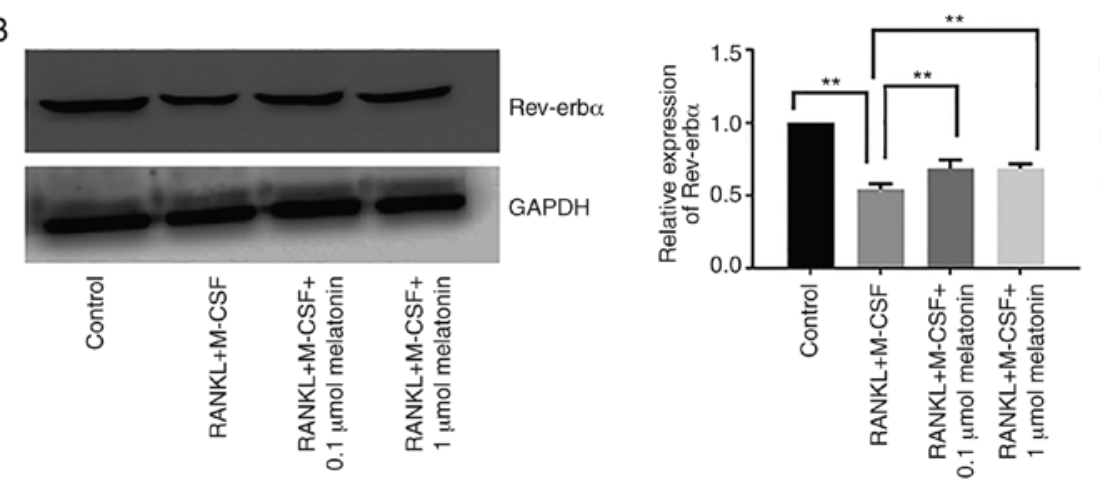

- Control

ㄹANKL+M-CSF

RANKL+M-CSF+

0.1 umol melatonin

RANKL+M-CSF+

1 umol melatonin

Figure 3. Rev-erbo expression in Raw264.7 cells is augmented by melatonin. Rev-erb $\alpha$ (A) mRNA and (B) protein expression in Raw264.7 cells cultured for 7 days with RANKL $(100 \mathrm{ng} / \mathrm{ml})$ and M-CSF $(30 \mathrm{ng} / \mathrm{ml})$ in the presence of varying concentrations $(0.1$ or $1 \mu \mathrm{mol})$ of melatonin for $48 \mathrm{~h}$. Data are represented as the mean $\pm \mathrm{SD}(\mathrm{n}=3) .{ }^{* * *} \mathrm{P}<0.01$. RANKL, receptor activator of nuclear factor- $\mathrm{kB}$ ligand; M-CSF, macrophage colony-stimulating factor; Rev-erb $\alpha / \mathrm{NR} 1 \mathrm{D} 1$, nuclear receptor subfamily 1 group $\mathrm{D}$ member 1 .
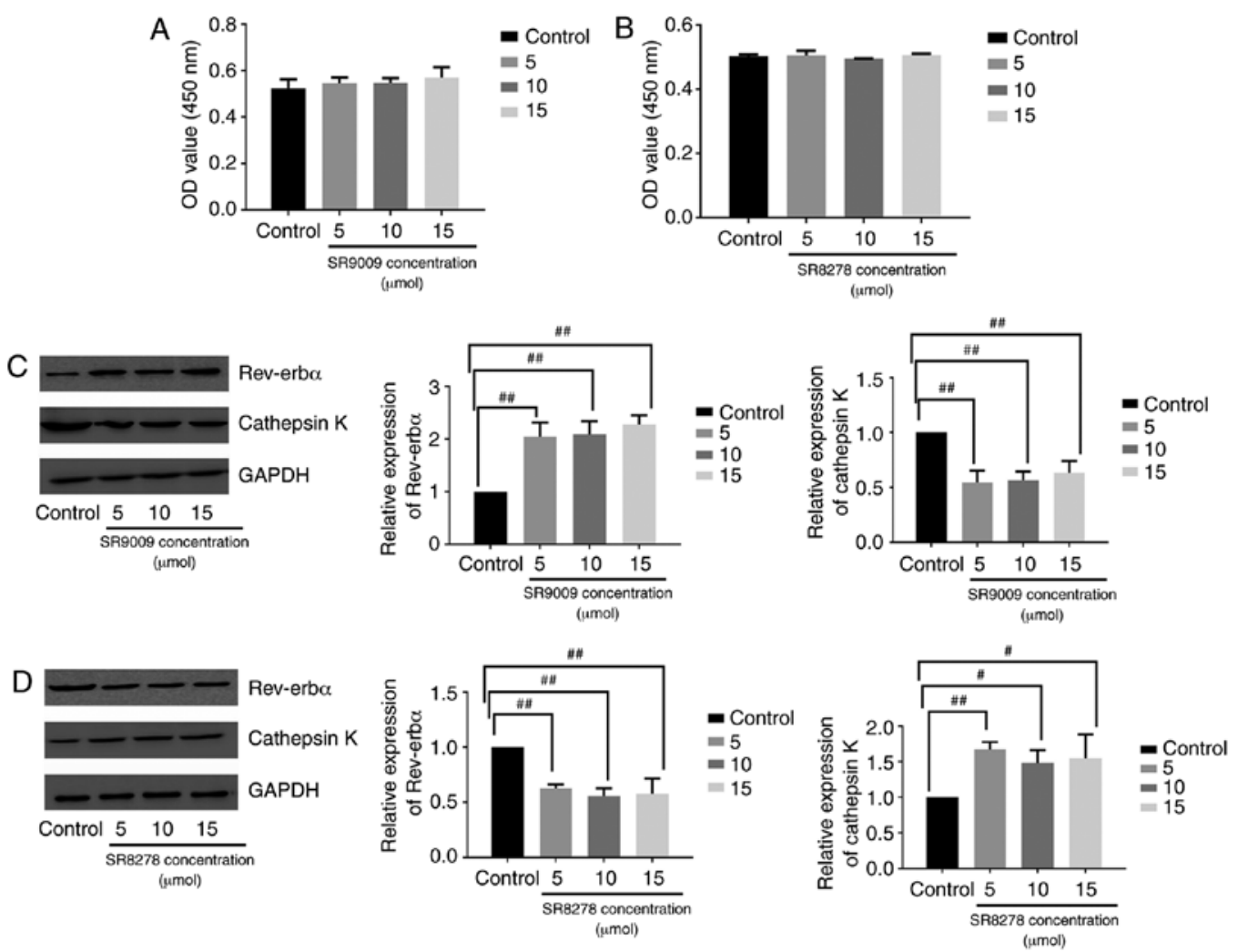

Figure 4. Rev-erb $\alpha$ activation increases the inhibitory effect of melatonin on Raw264.7 cell osteoclastogenesis, whereas the inhibition of Rev-erb $\alpha$ produces the opposite effect. Viability of Raw264.7 cells in the presence of varying concentrations of (A) SR9009 and (B) SR8278 (5, 10 and $15 \mu \mathrm{mol})$. Cell viability was expressed as OD value. Rev-erb $\alpha$ and cathepsin K expression in Raw264.7 cells cultured for 7 days with RANKL (100 ng/ml) and M-CSF (30 ng/ml), and for $48 \mathrm{~h}$ with $1 \mu \mathrm{mol}$ melatonin in the presence of varying concentrations of (C) SR9009 and (D) SR8278 (5, 10 and $15 \mu$ mol). Data are represented as the mean $\pm \mathrm{SD}(\mathrm{n}=3) .{ }^{\#} \mathrm{P}<0.05$ and ${ }^{\# \#} \mathrm{P}<0.01$. OD, optical density; RANKL, receptor activator of nuclear factor- $\mathrm{kB}$ ligand; M-CSF, macrophage colony-stimulating factor; Rev-erb $\alpha / N R 1 D 1$, nuclear receptor subfamily 1 group D member 1. 
A

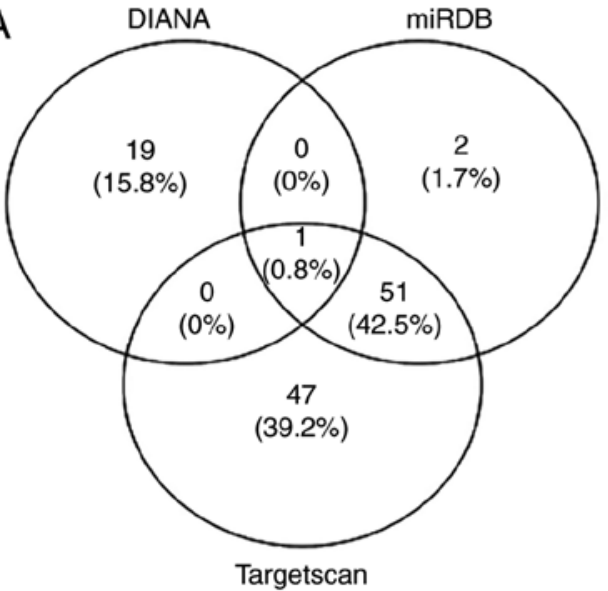

C
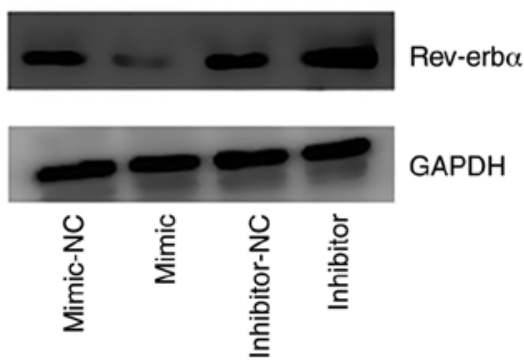

D mmu-miR-882 $33^{\prime}$ UgaUUaCgCGaUUGagagagGa $5^{\prime}$ III II IIIIIII| Nr1d1 5' AACUCUGCACU-UCUCUCUCCu $3^{\prime}$

mmu-miR-882 $\quad 3^{\prime}$ UGAUUACGCGAUUGAgAGagGa 5 III I| IIIIII|

Nr1d1 MUT 5' AACUCUGCACU-UAGAGAGAAu $3^{\prime}$
B
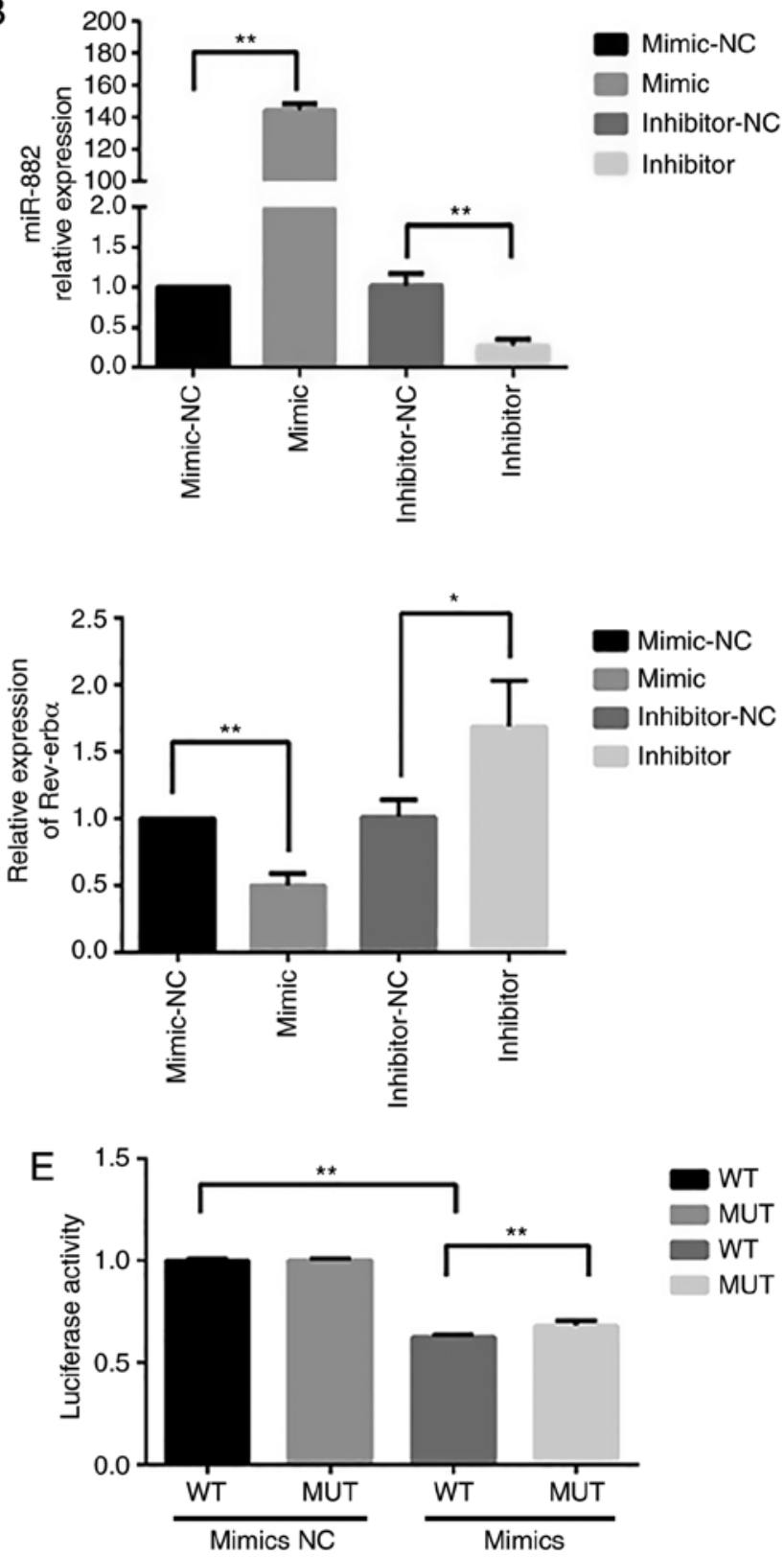

Figure 5. miR-882 targets Rev-erb $\alpha$. (A) Venn diagram of the miRNAs overlapping with Rev-erb $\alpha$ from three different databases (TargetScan, miRDB and DIANA). miR-882 was the only miRNA identified in all three databases that potentially regulated Rev-erb $\alpha$ expression. (B) Transfection efficiency of miR-882 mimic and inhibitors. (C) Rev-erb $\alpha$ protein expression after transfection with miR-882 mimics, inhibitors and corresponding NCs. (D) Binding sites for miR-882 and Rev-erba. (E) Luciferase activity in 293T cells co-transfected with miR-882 mimic and Rev-erba WT or MUT 3'-untranslated region. Data are represented as the mean $\pm \mathrm{SD}(\mathrm{n}=3)$. ${ }^{*} \mathrm{P}<0.05$ and ${ }^{* *} \mathrm{P}<0.01$. miRNA/miR, microRNA; NC, negative control; WT, wild-type; MUT, mutant; Rev-erba/NR1D1, nuclear receptor subfamily 1 group D member 1.

by miR-882 was examined. Transfection with miR-882 mimics significantly decreased Rev-erb $\alpha$ protein expression in Raw264.7 cells, whereas the inhibition of miR-882 produced the opposite effect (Fig. 5C). Next, the wild-type 3'-untranslated region (UTR) of Rev-erba mRNA was cloned with the presumed miR-882-binding sites, along with the mutant 3'-UTR located upstream of the luciferase-coding sequence (Fig. 5D). Luciferase activity was decreased in cells co-transfected with miR-882 mimics and Rev-erb $\alpha$ mRNA wild-type 3'-UTR fragments compared with in cells co-transfected with miR-882 mimics NC and Rev-erb $\alpha$ mRNA wild-type 3'-UTR fragments, and compared with in cells co-transfected with miR-882 mimics and Rev-erb $\alpha$ mRNA mutant 3'-UTR fragments (Fig. 5E). These results indicated that Rev-erb $\alpha$ may be a direct target of miR-882 and implied that miR-882 may exert its influence on osteoclastogenesis by targeting Rev-erba.

Melatonin downregulates miR-882 expression and the inhibition of miR-882 hinders RANKL-induced osteoclastogenesis. After demonstrating that Rev-erb $\alpha$ is a target gene of miR-882, whether miR-882 could regulate osteoclastogenesis was further explored. To determine the role of miR-882 in the inhibition of RANKL-induced osteoclastogenesis by melatonin, miR- 882 expression was examined in Raw264.7 cells cultured with RANKL and M-CSF in the 


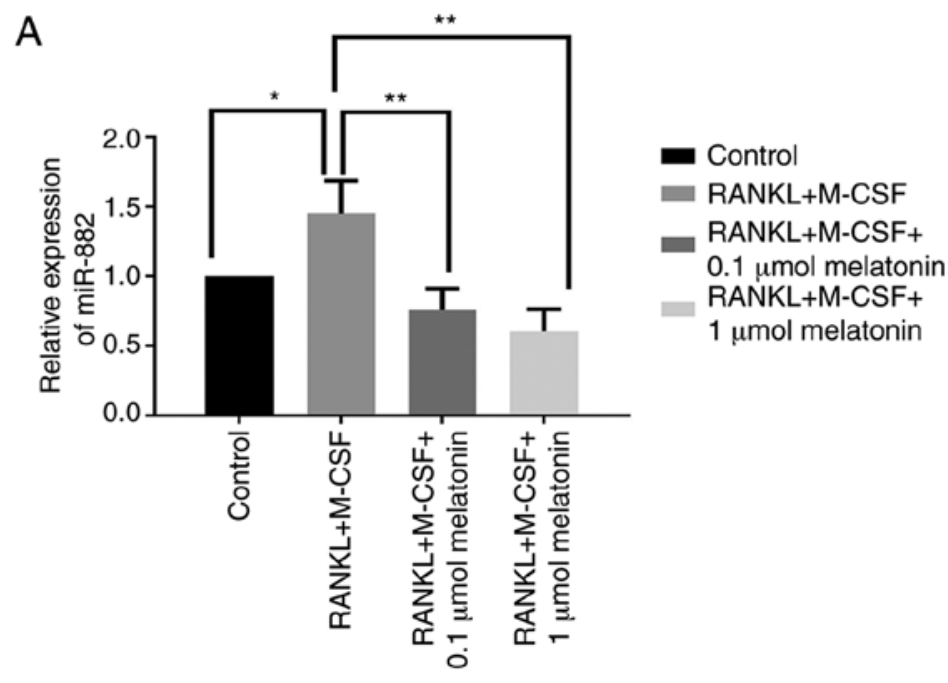

B
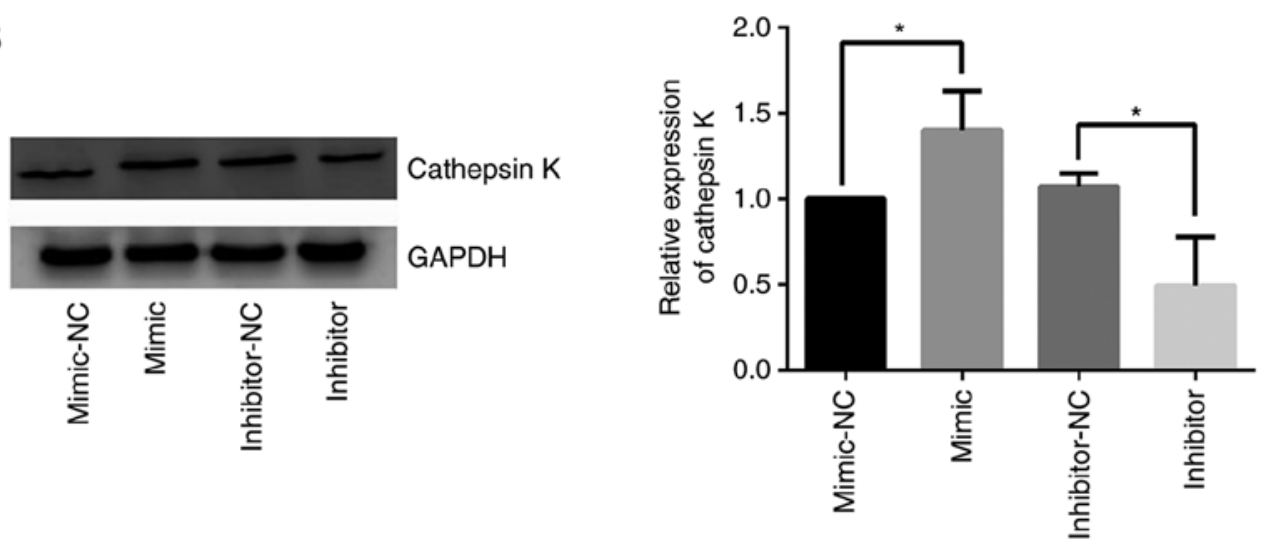

Mimic-NC Mimic Inhibitor-NC Inhibitor

Figure 6. Melatonin downregulates miR-882 expression in RANKL-induced Raw264.7 cells, whereas the overexpression of miR-882 promotes osteoclastogenesis in Raw264.7 cells. (A) miR-882 expression in Raw264.7 cells cultured for 7 days with RANKL (100 ng/ml) and M-CSF (30 ng/ml) in the presence of varying concentrations ( 0.1 or $1 \mu \mathrm{mol})$ of melatonin. (B) Cathepsin K expression after transfection with miR-882 mimics, inhibitors and corresponding NCs. Data are represented as the mean $\pm \mathrm{SD}(\mathrm{n}=3)$. ${ }^{*} \mathrm{P}<0.05$ and ${ }^{* *} \mathrm{P}<0.01$. RANKL, receptor activator of nuclear factor- $\kappa \mathrm{B}$ ligand; $\mathrm{M}-\mathrm{CSF}$, macrophage colony-stimulating factor; miR, microRNA; NC, negative control.

presence of varying concentrations of melatonin via reverse transcription-quantitative PCR. The results indicated that melatonin augmented Rev-erb $\alpha$ expression by decreasing miR-882 expression, resulting in decreased miR-882 expression compared with RANKL and M-CSF treatment (Fig. 6A). To further explore the function of miR-882 upon melatonin treatment, miR-882 mimics, inhibitors or corresponding NCs were transfected into Raw264.7 cells, and cathepsin $\mathrm{K}$ expression was examined. The overexpression of miR-882 upregulated cathepsin $\mathrm{K}$ expression compared with the mimic-NC; additionally, transfection with inhibitors decreased cathepsin $\mathrm{K}$ expression compared with the inhibitor-NC (Fig. 6B). The current results indicated that miR-882 inhibition may inhibit osteoclastogenesis to prevent osteoporosis, whereas the overexpression of miR-882 may promote osteoclastogenesis.

\section{Discussion}

Previous research has demonstrated that melatonin impacts osteoclastogenesis (44-47). Melatonin results in the concentration-dependent inhibition of osteoclastogenesis at pharmacological concentrations (44), which is consistent with the present findings. Notably, the inhibitory effect of melatonin may not be associated with the melatonin receptor, as demonstrated in a previous study (45). In an in vitro experiment with Transwell or layered mesenchymal stem cells and peripheral blood monocytes, melatonin inhibited osteoclastogenesis in the layered culture, but not the Transwell culture (46). Moreover, in vivo, melatonin can inhibit titanium particle-induced osteolysis (47). Thus, the present study examined the effect of melatonin on osteoclastogenesis, and the current data demonstrated that melatonin inhibited RANKL-induced osteoclastogenesis by promoting Rev-erb $\alpha$ expression via miR-882. The present results highlight the potential for melatonin in the treatment of osteoporosis. Osteoporosis is associated with clock genes, such as Rev-erba (48), Bmal1 (49) and cryptochrome circadian clocks 2 (50). Osteoporosis intervention such as oral salmon calcitonin, administration of teriparatide and pulsed electromagnetic field therapy at different time points in one day can provide different levels of bone protection, demonstrating the role of the circadian rhythm in the mechanisms of osteoporosis (51). The parathyroid hormone-responsive circadian clock serves a crucial role in the process of mouse femur fracture healing (52). 


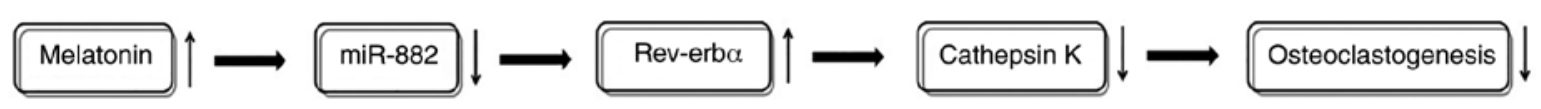

Figure 7. Potential mechanism by which melatonin may affect RANKL-induced osteoclastogenesis. Melatonin may first decrease miR-882 expression, then augment Rev-erb $\alpha$ expression and decrease cathepsin $\mathrm{K}$ expression, ultimately inhibiting osteoclastogenesis. RANKL, receptor activator of nuclear factor- $\mathrm{K}$ ligand; miR, microRNA; Rev-erba/NR1D1, nuclear receptor subfamily 1 group D member 1.

A previous study has demonstrated that certain proteins encoded by clock genes, such as Rev-erb $\alpha$, a member of the NR1D1, are expressed rhythmically in Raw264.7 cells (53). Rev-erb $\alpha$, which is present in abundant levels in adipose cells, macrophages and muscle cells, was reported to govern the circadian rhythm, as well as lipid and glucose metabolism (54). Additionally, it serves a crucial role in inflammatory reactions and diseases, including diabetes and atherosclerosis, by suppressing the transcription and translation of downstream genes $(55,56)$. Rev-erb $\alpha$ is a critical component of the biological clock and one of the important participants in regulating biological rhythms (57). Furthermore, other studies have demonstrated that the abnormal expression levels of Rev-erba are closely associated with diseases, such as osteoporosis (48), acute myocardial infarction (58), Alzheimer's disease (59) and skeletal muscle myopathies (60). SR9009, the biological effect of which is caused by an interaction with Rev-erba, is a Rev-erb $\alpha$ agonist (61). SR9009 can enhance basal metabolism by raising oxygen consumption, enriching mitochondrial content and accelerating glucose and fatty acid metabolism in skeletal muscle (62). In addition, SR9009 decreases the synthesis of lipids, cholesterol and bile acid in the liver, and downregulates fat reserves in white adipose tissue based on in vitro and in vivo experiments (63). SR8278 is structurally similar to SR9009, but functionally different (64). SR8278 can promote microglia polarization toward a phagocytic M2-like phenotype during which purinergic receptor $\mathrm{P} 2 \mathrm{Y}_{12} \mathrm{R}$ expression is upregulated (65). Previous studies corroborate the present finding that Rev-erb $\alpha$ impacts osteoclastogenesis $(48,66)$. For example, the Rev-erba agonist SR9009 inhibits osteoclastogenesis in postmenopausal mice by upregulating fatty acid binding protein 4 (66). This demonstrates that Rev-erbo is a crucial component in the inhibition of osteoclast differentiation. Furthermore, it may be closely associated with the occurrence and development of osteoporosis.

miRNAs are non-coding RNAs that contain 21-23 nucleotides and exert their influence by binding to the 3'-UTR of target mRNAs to inhibit their translation (67). The present study identified a new interaction between miRNAs and Rev-erb $\alpha$ during osteoclastogenesis using online databases. The current results indicated that Rev-erb $\alpha$ could be regulated by miRNAs binding to the 3'-UTR of Rev-erbo mRNA. miR-882 is localized to chromosome 12 on GRCm38.p6, and, to the best of our knowledge, an association between miR-882 and osteoporosis has not yet been reported. The present results indicated that miR-882 promoted osteoporosis by binding to the Rev-erb $\alpha$ 3'-UTR, inhibiting Rev-erb $\alpha$ translation, and thereby negatively regulating Rev-erb $\alpha$ expression. In the present study, miR-882 expression was decreased upon melatonin treatment. Additionally, the inhibition of miR-882 hampered osteoclastogenesis, whereas the miR-882 overexpression promoted osteoclastogenesis. Thus, the downregulation of miR-882 may represent a potential strategy to treat osteoporosis by stalling osteoclastogenesis. However, further studies on the role of miR-882 in protein signalling pathways to regulate diverse biological behaviours are required.

Calcium and vitamin D can be used to treat osteoporosis, but they result in severe side effects (68). A prior meta-analysis reported that the small risk of significant adverse effects, such as kidney stones, myocardial infarction, hypercalcemia and hospitalization with acute gastrointestinal symptoms, together with the moderate risk of minor side effects, including constipation, probably outweighs any benefits of calcium supplements used for the treatment of fractures (68).

In conclusion, the present study demonstrated that the miR-882/Rev-erb $\alpha$ axis may serve a vital role in osteoporosis, suggesting that melatonin may first decrease miR-882 expression, followed by elevating Rev-erb $\alpha$ expression and then lowering cathepsin $\mathrm{K}$ expression, and finally inhibiting osteoclastogenesis (Fig. 7). Thus, miR-882 and Rev-erb $\alpha$ comprise a potential novel therapeutic dual-target mechanism through which melatonin may impact osteoporosis. The role of non-coding RNAs and circadian rhythms in the progression of osteoporosis was explored to provide a basis for the application of melatonin to sensitize osteoporotic cells, and potentially patients, to drug treatment in the future.

\section{Acknowledgements}

Not applicable.

\section{Funding}

The present study was supported by the Natural Science Foundation of Liao Ning (grant no. 2019-BS-294) and the Construction of Clinical Medical Research Center of Orthopaedics and Sports Rehabilitation Diseases in Liaoning Province (grant no. 2019416030).

\section{Availability of data and materials}

The datasets used and/or analyzed during the current study are available from the authors on reasonable request.

\section{Authors' contributions}

YT and YZ contributed to the conception and design. YT, ZG and RZ performed cell cultures. YT, ZG, RZ and YZ contributed to acquisition and analysis of data, revising the manuscript critically for important intellectual content, and approved the manuscript for publication. YT and ZG performed the statistical analysis and manuscript preparation. $\mathrm{YZ}$ obtained funding for the study and approved the final version of the manuscript. All authors read and approved the final version of the manuscript. 


\section{Ethics approval and consent to participate}

Not applicable.

\section{Patient consent for publication}

Not applicable.

\section{Competing interests}

The authors declare that they have no competing interest.

\section{References}

1. Gosch M, Kammerlander C and Nicholas JA: Treatment of osteoporosis in older adults. Panminerva Med 56: 133-143, 2014.

2. Kurra S, Fink DA and Siris ES: Osteoporosis-associated fracture and diabetes. Endocrinol Metab Clin North Am 43: 233-243, 2014

3. Maeda SS and Lazaretti-Castro M: An overview on the treatment of postmenopausal osteoporosis. Arq Bras Endocrinol Metabol 58: 162-171, 2014.

4. Yun H, Delzell E, Saag KG, Kilgore ML, Morrisey MA, Muntner P, Matthews R, Guo L, Wright N, Smith W, et al: Fractures and mortality in relation to different osteoporosis treatments. Clin Exp Rheumatol 33: 302-309, 2015.

5. Hegyi L: The risk of immobility in geriatrics. Eurorehab 3 : 151-154, 2001

6. Rachner TD, Khosla S and Hofbauer LC: Osteoporosis: Now and the future. Lancet 377: 1276-1287. 2011.

7. Malluche HH, Koszewski N, Monier-Faugere MC, Williams JP and Mawad $\mathrm{H}$ : Influence of the parathyroid glands on bone metabolism. Eur J Clin Invest 36: (Suppl 2): S23-S33, 2006.

8. Li B, Wang Y, Liu Y, Ma J and Li Y: Altered gene expression involved in insulin signaling pathway in type II diabetic osteoporosis rat model. Endocrine 43: 136-146, 2013

9. Kameda Y, Takahata M, Mikuni S, Shimizu T, Hamano H, Angata T, Hatakeyama S, Kinjo M and Iwasaki N: Siglec-15 is a potential therapeutic target for postmenopausal osteoporosis. Bone 71: 217-226, 2015.

10. Canalis E: Wnt signalling in osteoporosis: Mechanisms and nove therapeutic approaches. Nat Rev Endocrinol 9: 575-583, 2013.

11. Manolagas SC: Wnt signaling and osteoporosis. Maturitas 78 233-237, 2014

12. Hu J, Mao Z, He S, Zhan Y, Ning R, Liu W, Yan B and Yang J: Icariin protects against glucocorticoid induced osteoporosis, increases the expression of the bone enhancer DEC1 and modulates the PI3K/Akt/GSK3 $/ / \beta$-catenin integrated signaling pathway. Biochem Pharmacol 136: 109-121, 2017.

13. Liu Y, Wang X, Chang H, Gao X, Dong C, Li Z, Hao J, Wang J and Fan Q: Mongolian Medicine echinops prevented postmenopausal osteoporosis and induced ER/AKT/ERK pathway in BMSCs. Biosci Trends 12: 275-281, 2018.

14. Cong Q, Jia H, Li P, Qiu S, Yeh J, Wang Y, Zhang ZL, Ao J, Li B and Liu H: p38alpha MAPK regulates proliferation and differentiation of osteoclast progenitors and bone remodeling in an aging-dependent manner. Sci Rep 7: 45964, 2017.

15. Pan BL, Tong ZW, Li SD, Wu L, Liao JL, Yang YX, Li HH, Dai YJ, Li JE and Pan L: Decreased microRNA-182-5p helps alendronate promote osteoblast proliferation and differentiation in osteoporosis via the Rap1/MAPK pathway. Biosci Rep 38 : BSR20180696, 2018.

16. Dong W, Qi M, Wang Y, Feng X and Liu H: Zoledronate and high glucose levels influence osteoclast differentiation and bone absorption via the AMPK pathway. Biochem Biophys Res Commun 505: 1195-1202, 2018.

17. de Pablos RM, Espinosa-Oliva AM, Hornedo-Ortega R, Cano M and Arguelles S: Hydroxytyrosol protects from aging process via AMPK and autophagy, a review of its effects on cancer, metabolic syndrome, osteoporosis, immune-mediated and neurodegenerative diseases. Pharmacol Res 143: 58-72, 2019.

18. Buchwald ZS, Yang C, Nellore S, Shashkova EV, Davis JL, Cline A, Ko J, Novack DV, DiPaolo R and Aurora R: A bone anabolic effect of RANKL in a murine model of osteoporosis mediated through FoxP3 ${ }^{+}$CD8 $\mathrm{T}$ cells. J Bone Miner Res 30: $1508-1522,2015$.
19. Qi J, Hu KS and Yang HL: Roles of TNF- $\alpha$, GSK-3 $\beta$ and RANKL in the occurrence and development of diabetic osteoporosis. Int J Clin Exp Pathol 8: 11995-2004, 2015.

20. Guo L, Tang K, Quan Z, Zhao Z and Jiang D: Association between seven common OPG genetic polymorphisms and osteoporosis risk: A meta-analysis. DNA Cell Biol 33: 29-39, 2014.

21. Lin H, Zhang G, Chen X, Wu X, Wu C, Ca H and Hu Z: The relationship between the . $27450 \mathrm{~A}>\mathrm{T}$ genetic variant of $\mathrm{OPG}$ gene and osteoporosis in Chinese postmenopausal women. Int Immunopharmacol 21: 464-467, 2014.

22. Brunetti G, Storlino G, Oranger A, Colaianni G, Faienza MF, Ingravallo G, Di Comite M, Reseland JE, Celi M, Tarantino U, et al: LIGHT/TNFSF14 regulates estrogen deficiency-induced bone loss. J Pathol 250: 440-451, 2020.

23. Wang X, Liang T, Zhu Y, Qiu J, Qiu X, Lian C, Gao B, Peng Y, Liang A, Zhou H, et al: Melatonin prevents bone destruction in mice with retinoic acid-induced osteoporosis. Mol Med 25: 43, 2019.

24. Negishi-Koga $\mathrm{T}$ and Takayanagi $\mathrm{H}: \mathrm{Ca}^{2+}-\mathrm{NFATc1}$ signaling is an essential axis of osteoclast differentiation. Immunol Rev 231: 241-256, 2009.

25. An J, Hao D, Zhang Q, Chen B, Zhang R, Wang Y and Yang H: Natural products for treatment of bone erosive diseases: The effects and mechanisms on inhibiting osteoclastogenesis and bone resorption. Int Immunopharmacol 36: 118-131, 2016.

26. Ledesma-Colunga MG, Adán N, Ortiz G, Solís-Gutiérrez M, López-Barrera F, Martínez de la Escalera G and Clapp C: Prolactin blocks the expression of receptor activator of nuclear factor $\kappa \mathrm{B}$ ligand and reduces osteoclastogenesis and bone loss in murine inflammatory arthritis. Arthritis Res Ther 19: 93, 2017.

27. Chai L, Zhou K, Wang S, Zhang H, Fan N, Li J, Tan X, Hu L and Fan X: Psoralen and bakuchiol ameliorate M-CSF plus RANKL-induced osteoclast differentiation and bone resorption via inhibition of AKT and AP-1 pathways in vitro. Cell Physiol Biochem 48: 2123-2133. 2018.

28. Liu W and Zhang X: Receptor activator of nuclear factor- $\kappa \mathrm{B}$ ligand (RANKL)/RANK/osteoprotegerin system in bone and other tissues (review). Mol Med Rep 11: 3212-3218, 2015.

29. Park JH, Lee NK and Lee SY: Current understanding of RANK signaling in osteoclast differentiation and maturation. Mol Cells 40: 706-713, 2017.

30. Naidu VG, Dinesh Babu KR, Thwin MM, Satish RL, Kumar V and Gopalakrishnakone P: RANKL targeted peptides inhibit osteoclastogenesis and attenuate adjuvant induced arthritis by inhibiting $\mathrm{NF}-\kappa \mathrm{B}$ activation and down regulating inflammatory cytokines. Chem Biol Interact 203: 467-479, 2013.

31. Qin S, Zhang Q and Zhang L: Effect of OPG gene mutation on protein expression and biological activity in osteoporosis. Exp Ther Med 14: 1475-1480, 2017.

32. Dai XM, Ryan GR, Hapel AJ, Dominguez MG, Russell RG, Kapp S, Sylvestre V and Stanley ER: Targeted disruption of the mouse CSF-1 receptor gene results in osteopetrosis, mononuclear phagocyte deficiency, increased primitive progenitor cell frequencies and reproductive defects. Blood 99: 111-120, 2002.

33. Cheng C, Wentworth K and Shoback DM: New frontiers in osteoporosis therapy. Annu Rev Med 71: 277-288, 2020.

34. Claustrat B and Leston J: Melatonin: Physiological effects in humans. Neurochirurgie 61: 77-84, 2015.

35. Tan DX and Reiter RJ: Mitochondria: The birth place, battle ground and the site of melatonin metabolism in cells. Melat Res 2: 44-66, 2019

36. Claustrat B, Geoffriau M, Brun J and Chazot G: Melatonin in humans: A biochemical marker of the circadian clock and an endogenous synchronizer. Neurophysiol Clin 25: 351-359, 1995 (In French).

37. Vural EM, van Munster BC and de Rooij SE: Optimal dosages for melatonin supplementation therapy in older adults: A systematic review of current literature. Drugs Aging 31: 441-451, 2014.

38. van Faassen M, Bischoff R and Kema IP: Relationship between plasma and salivary melatonin and cortisol investigated by LC-MS/MS. Clin Chem Lab Med 55: 1340-1348, 2017.

39. Claustrat B, Brun J and Chazot G: The basic physiology and pathophysiology of melatonin. Sleep Med Rev 9: 11-24, 2005.

40. Amaral FGD and Cipolla-Neto J: A brief review about melatonin, a pineal hormone. Arch Endocrinol Metab 62: 472-479, 2018

41. Sánchez-Barceló EJ, Mediavilla MD, Tan DX and Reiter RJ: Scientific basis for the potential use of melatonin in bone diseases: Osteoporosis and adolescent idiopathic scoliosis. J Osteoporos 2010: 830231, 2010.

42. Livak KJ and Schmittgen TD: Analysis of relative gene expression data using real-time quantitative PCR and the 2(-Delta Delta C(T)) method. Methods 25: 402-408, 2001. 
43. Jacome-Galarza CE, Percin GI, Muller JT, Mass E, Lazarov T, Eitler J, Rauner M, Yadav VK, Crozet L, Bohm M, et al: Developmental origin, functional maintenance and genetic rescue of osteoclasts. Nature 568: 541-545, 2019.

44. Zhou L, Chen X, Yan J, Li M, Liu T, Zhu C, Pan G, Guo Q, Yang H, Pei M and He F: Melatonin at pharmacological concentrations suppresses osteoclastogenesis via the attenuation of intracellular ROS. Osteoporos Int 28: 3325-3337, 2017.

45. Kim HJ, Kim HJ, Bae MK and Kim YD: Suppression of osteoclastogenesis by melatonin: A melatonin receptor-independent action. Int J Mol Sci 18: 1142, 2017.

46. Sifat M, Samsonraj RM, Munmun F, Glas J, Silvestros M, Kotlarczyk MP, Rylands R, Dudakovic A, van Wijnen AJ, Enderby LT, et al: Biological effects of melatonin on osteoblast/osteoclast cocultures, bone, and quality of life: Implications of a role for MT2 melatonin receptors, MEK1/2, and MEK5 in melatonin-mediated osteoblastogenesis. J Pineal Res 64, 2018.

47. Ping Z, Wang Z, Shi J, Wang L, Guo X, Zhou W, Hu X, Wu X, Liu Y, Zhang W, et al: Inhibitory effects of melatonin on titanium particle-induced inflammatory bone resorption and osteoclastogenesis via suppression of NF- $\kappa \mathrm{B}$ signaling. Acta Biomater 62: 362-371, 2017.

48. Song C, Tan P, Zhang Z, Wu W, Dong Y, Zhao L, Liu H, Guan H and Li F: REV-ERB agonism suppresses osteoclastogenesis and prevents ovariectomy-induced bone loss partially via FABP4 upregulation. FASEB J 32: 3215-3228, 2018.

49. Zhou X, Yu R, Long Y, Zhao J, Yu S, Tang Q and Chen L: BMAL1 deficiency promotes skeletal mandibular hypoplasia via OPG downregulation. Cell Prolif 51: e12470, 2018.

50. Tang $\mathrm{Z}, \mathrm{Xu} \mathrm{T}, \mathrm{Li} \mathrm{Y}, \mathrm{Fei} \mathrm{W}$, Yang $\mathrm{G}$ and Hong Y: Inhibition of CRY2 by STAT3/miRNA-7-5p promotes osteoblast differentiation through upregulation of CLOCK/BMAL1/P300 expression. Mol Ther Nucleic Acids 19: 865-876, 2020.

51. Song C, Wang J, Kim B, Lu C, Zhang Z, Liu H, Kang H, Sun Y, Guan H, Fang Z and Li F: Insights into the role of circadian rhythms in bone metabolism: A promising intervention target? BioMed Res Int 2018: 9156478, 2018.

52. Kunimoto T, Okubo N, Minami Y, Fujiwara H, Hosokawa T, Asada M, Oda R, Kubo T and Yagita K: A PTH-responsive circadian clock operates in ex vivo mouse femur fracture healing site. Sci Rep 6, $22409,2016$.

53. Gibbs JE, Blaikley J, Beesley S, Matthews L, Simpson KD, Boyce SH, Farrow SN, Else KJ, Singh D, Ray DW and Loudon AS: The nuclear receptor REV-ERB $\alpha$ mediates circadian regulation of innate immunity through selective regulation of inflammatory cytokines. Proc Natl Acad Sci USA 109: 582-587, 2012.

54. Vieira E, Merino B and Quesada I: Role of the clock gene Rev-erbalpha in metabolism and in the endocrine pancreas. Diabetes Obes Metab 17 (Suppl 1): S106-S114, 2015.

55. Lam MT, Cho H, Lesch HP, Gosselin D, Heinz S, Tanaka-Oishi Y Benner C, Kaikkonen MU, Kim AS, Kosaka M, et al: Rev-Erbs repress macrophage gene expression by inhibiting enhancer-directed transcription. Nature 498: 511-515, 2013.
56. Sato S, Sakurai T, Ogasawara J, Takahashi M, Izawa T, Imaizumi K, Taniguchi N, Ohno $\mathrm{H}$ and Kizaki T: A circadian clock gene, Rev-erb $\alpha$, modulates the inflammatory function of macrophages through the negative regulation of $\mathrm{Ccl} 2$ expression. J Immunol 192: 407-417, 2014.

57. Mazzoccoli G, Cai Y, Liu S, Francavilla M, Giuliani F, Piepoli A, Pazienza V, Vinciguerra M, Tamamoto $\mathrm{T}$ and Takumi T: REV-ERBalpha and the clock gene machinery in mouse peripheral tissues: A possible role as a synchronizing hinge. J Biol Regul Homeost Agents 26: 265-276, 2012.

58. Wang S, Gu X, Zhang Q, Zhang X, Li Y, Yao Y, Yu B and Zhang Y: Angiotensin II suppresses Rev-erba expression in THP-1 macrophages via the Ang II type 1 receptor/liver X receptor $\alpha$ pathway. Cell Physiol Biochem 46: 303-313, 2018.

59. Roby DA, Ruiz F, Kermath BA, Voorhees JR, Niehoff M, Zhang J, Morley JE, Musiek ES, Farr SA and Burris TP: Pharmacological activation of the nuclear receptor REV-ERB reverses cognitive deficits and reduces amyloid- $\beta$ burden in a mouse model of Alzheimer's disease. PloS One 14: e0215004, 2019.

60. Welch RD and Flaveny CA: REV-ERB and ROR: Therapeutic targets for treating myopathies. Phys Biol 14: 045002, 2017.

61. Solt LA, Wang Y, Banerjee S, Hughes T, Kojetin DJ, Lundasen T, Shin Y, Liu J, Cameron MD, Noel R, et al: Regulation of circadian behavior and metabolism by synthetic REV-ERB agonists. Nature 485: 62-68, 2012.

62. Thevis $M$ and Schänzer W: Emerging drugs affecting skeletal muscle function and mitochondrial biogenesis - Potential implications for sports drug testing programs. Rapid Commun Mass Spectrom 30: 635-651, 2016.

63. Mazzarino M, Rizzato N, Stacchini C, de la Torre X and Botrè F: A further insight into the metabolic profile of the nuclear receptor Rev-erb agonist, SR9009. Drug Test Anal 10: 1670-1681, 2018.

64. Kojetin D, Wang Y, Kamenecka TM and Burris TP: Identification of SR8278, a synthetic antagonist of the nuclear heme receptor REV-ERB. ACS Chem Biol 6: 131-134, 2011.

65. Lee J, Kim DE, Griffin P, Sheehan PW, Kim DH, Musiek ES and Yoon SY: Inhibition of REV-ERBs stimulates microglial amyloid-beta clearance and reduces amyloid plaque deposition in the 5XFAD mouse model of Alzheimer's disease. Aging Cell 19: e13078, 2020

66. Kim K, Kim JH, Kim I, Seong S and Kim N: Rev-erb $\alpha$ Negatively Regulates Osteoclast and Osteoblast Differentiation through p38 MAPK Signaling Pathway. Mol Cells 43: 34-47, 2020.

67. Carthew RW and Sontheimer EJ: Origins and mechanisms of miRNAs and siRNAs. Cell 136: 642-655, 2009.

68. Bolland MJ, Grey A and Reid IR: Should we prescribe calcium or vitamin D supplements to treat or prevent osteoporosis. Climacteric 18 (Suppl 2): S22-S31, 2015.

This work is licensed under a Creative Commons

Attribution-NonCommercial-NoDerivatives 4.0

International (CC BY-NC-ND 4.0) License. 